\title{
ANALISIS MODEL PERIODIK DITINJAU DARI CURAH HUJAN HARIAN DARI BEBERAPA STASIUN DI SUB DAS WAY KANDIS
}

\author{
Oleh \\ Farida Juwita ${ }^{1}$ \\ Dosen Tetap Fakultas Teknik USBRJ \\ email : ida_juwita@yahoo.com
}

\begin{abstract}
ABSTRAK
Indonesia sejak dahulu sudah dikenal sebagai negara agraris karena sebagian besar penduduknya bermatapencaharian sebagai petani. Dengan demikian diperlukan pengelolaan yang baik untuk meningkatkan produksi pertanian tersebut. Salah satu faktor utama penunjang keberhasilan program tersebut adalah perbaikan sarana irigasi, pembangunan bangunan air seperti bendungan dan revitalisasi jaringan irigasi perlu ditingkatkan dan dikembangkan.

Variasi perbandingan besarnya parameter periodik dan stokastik dapat ditentukan menggunakan pemodelan yang membutuhkan data masukan berupa data curah hujan. Model periodik dan stokastik curah hujan dihasilkan dengan menguraikan data curah hujan menjadi komponen-komponen periodik dan stokastik sebagai pembanding antara data curah hujan dengan pemodelan. Untuk membuktikan satu seri pencatatan dari data hujan adalah sangat sulit, sehingga terkadang untuk meramal atau menambah data pencatatan hujan, pembuatan simulasi data hujan sintetik diperlukan.

Dengan melihat karakteristik curah hujan daerah Way Kandis yang dihasilkan dari model tersebut, dapat dilakukan simulasi curah hujan harian sintetik yang lebih akurat dari pada simulasi yang hanya mempergunakan model periodik curah hujan harian Way Kandis. Model ini bisa dipergunakan untuk menghasilkan data hujan buatan yang sangat akurat dan realistis dipergunakan untuk perencanaan irigasi atau proyek sumber daya air di masa yang akan datang untuk daerah Way Kandis.Dengan menggunakan metode transformasi dapat menghasilkan data curah hujan harian sintetik seri waktu yang hasilnya mendekati data curah hujan terukur.

Spektrum curah hujan dari data curah hujan seri waktu digunakan sebagai masukan untuk menghasilkan program periodik stokastik curah hujan buatan untuk mensimulasikan data curah hujan sintetik. Dengan adanya komponen stokastik curah hujan, model curah hujan harian sintetik yang dihasilkan menjadi sangat akurat dengan koefisien korelasi ratarata model periodik adalah 0,9165. Nilai koefisien korelasi yang dihasilkan hampir mendekati 1, sehingga dapat disimpulkan bahwa metode FFT sangat akurat untuk menghasilkan curah hujan harian sintetik yang signifikan.
\end{abstract}

Kata kunci : agraris, hujan, irigasi, periodik, stokastik, model.

\section{THE ANALYSIS OF PERIODICALLY MODEL REVIEWED BY DAILY RAINFALL AT SOME STATIONS IN SUB DAS WAY KANDIS}

By:

Farida Juwita

Email: ida juwita@yahoo.com

\footnotetext{
${ }^{1}$ Staf Pengajar Jurusan Teknik Sipil Fakultas TeknikUniversitasSang Bumi Ruwa Jurai
} 


\begin{abstract}
Since the first time, Indonesia has been known as an agricultural country because of the most population livelihood as farmers. This is due to the climate in Indonesia is a tropical climate. It is very helpful for agricultural commodities as seed production. So that, this good management to increase the agricultural production is conducted. One of the main factors supporting the success of the program is the improvement of irrigation facilities, the water constructions like dams and irrigation revitalization need to be improved and developed.

Variation of the magnitude of periodic and stochastic parameters can be determined using modeling which requires data input of rainfall data. Periodic and stochastic models of rainfall generated by outlining the rainfall data into components periodic and stochastic as a comparison between rainfall data with modeling. To prove a series of records from the rainfall data is very difficult, so sometimes to predict rain or add data recording, manufacture of synthetic rainfall data simulation is required.

By looking at the characteristics of the rainfall in Way Kandis generated from the model, can be simulated synthetic daily rainfall is more accurate than using only simulation models periodic daily rainfall Way Kandis. This model can be used to produce artificial rain data is highly accurate and realistic planning is used for irrigation or water resource projects in the future for the area Way Kandis. By using the transformation method, it can produce synthetic daily rainfall data time series results approached measurable rainfall data.

The spectrum of rainfall from the time series of rainfall data is used as input to generate a periodic program stochastic artificial rainfall to simulate synthetic rainfall data. With the stochastic component of rainfall, daily rainfall synthetic models produced to be very accurate with the average correlation coefficient was 0.9165 periodic models. The resulting correlation coefficient value almost close to 1 , so it can be concluded that the $\Gamma$ is very accurate method for generating synthetic daily rainfall is significant.
\end{abstract}

Keywords: agriculture, rainfall, irrigation, periodic stochastic models.

\section{PENDAhULUAN}

Indonesia sejak dahulu sudah dikenal sebagai negara agraris karena sebagian besar penduduknya bermatapencaharian sebagai petani. Salah satu faktor utama penunjang keberhasilan program tersebut adalah perbaikan sarana irigasi, pembangunan bangunan air seperti bendungan dan revitalisasi jaringan irigasi perlu ditingkatkan dan dikembangkan.

Dalam merencanakan sistem irigasi, diperlukan banyak data hidrologi, selain diperlukan data debit. Kaitannya dengan data tersebut, salah satu data yang sangat penting yaitu informasi detail mengenai tinggi curah hujan bagi pihak perencana terutama untuk perencanaan bangunan air. Data curah hujan inilah yang menjadi parameter penting sebagai dasar perhitungan dalam merencanakan berbagai bangunan air. Besaran yang digunakan sebagai besaran rancangan (design value) ini berupa besaran hujan maupun besaran debit. Selain sebagai keperluan perencanaan bangunan air, 
dapat digunakan pula dalam upaya penyediaan air untuk irigasi atau air minum, pembangkitan tenaga listrik dan sebagainya. Tetapi untuk mendapatkan data curah hujan secara lengkap masih terdapat beberapa kendala, di antaranya adalah kurang tersedianya alat pengukur curah hujan, kurangnya tenaga pelaksana yang terampil, kurang baiknya cara penyimpanan data, sukarnya komunikasi antara tempat-tempat pengumpulan data dengan pengukuran curah hujan dan lain sebagainya yang memungkinkan adanya data yang hilang sehingga menghambat proses perencanaan bangunan air.

Hujan merupakan fenomena alam yang dipengaruhi oleh parameter iklim seperti suhu udara, kelembaban, dan arah angin, yang memiliki sifat periodik dan stokastik. Pengaruh paramater hujan yang bersifat periodik dan stokastik besarnya bervariasi terhadap besarnya curah hujan. Variasi perbandingan besarnya parameter periodik dan stokastik dapat ditentukan menggunakan pemodelan yang membutuhkan data masukan berupa data curah hujan. Model periodik dan stokastik curah hujan dihasilkan dengan menguraikan data curah hujan menjadi komponen-komponen periodik dan stokastik sebagai pembanding antara data curah hujan dengan pemodelan. Untuk membuktikan satu seri pencatatan dari data hujan adalah sangat sulit, sehingga terkadang untuk meramal atau menambah data pencatatan hujan, pembuatan simulasi data hujan sintetik diperlukan. Dengan melihat karakteristik curah hujan daerah Way Kandis yang dihasilkan dari model tersebut, dapat dilakukan simulasi curah hujan harian sintetik yang lebih akurat dari pada simulasi yang hanya mempergunakan model periodik curah hujan harian Way Kandis. Model ini bisa dipergunakan untuk menghasilkan data hujan buatan yang sangat akurat dan realistis dipergunakan untuk perencanaan irigasi atau proyek sumber daya air di masa yang akan datang untuk daerah Way Kandis.

\section{METODOLOGI}

\section{Wilayah Studi}

Wilayah studi dari penelitian ini adalah beberapa stasiun curah hujan di wilayah Kandis, Kota Bandar Lampung, Propinsi Lampung, Indonesia. Stasiun curah hujan yang diteliti yaitu stasiun Negara Ratu Natar, stasiun Way Kandis Besar, dan stasiun Way Semah

\section{Data yang Digunakan}

Data yang digunakan dalam penelitian ini adalah data sekunder, dimana data sekunder yang dipakai adalah berupa data curah hujan harian yang didapat dari Balai Besar Wilayah 
Sungai Mesuji-Sekampung (BBWSM) untuk beberapa stasiun yang bertempat di wilayah Way Kandis. Dari beberapa stasiun hujan yang ada di wilayah tersebut, hanya 3 (tiga) lokasi stasiun curah hujan yang digunakan yaitu Stasiun Negara Ratu Natar stasiun Way Kandis Besar, dan stasiun Way Semah. Panjang waktu data curah hujan dari setiap stasiun dalam penelitian ini menggunakan waktu dengan periode 16 tahun (1997-2013).

\section{Analisis Data}

Data sekunder yang telah diperoleh kemudian dianalisis dengan menggunakan program. Program tersebut nantinya saling berkaitan satu sama lain sehingga untuk menjalankan program yang lain tergantung pada output program sebelumnya. Hal yang pertama kali dilakukan yaitu pengolahan data sekunder yang berupa data curah hujan harian dalam bentuk digital (tabel excel) dari beberapa stasiun curah hujan yang ada di wilayah Way Kandis. Data tersebut sebelum diolah diurutkan terlebih dahulu menjadi data dalam bentuk time series, dari data terlama sampai dengan data yang paling baru. Data inilah yang selanjutnya diolah atau dilakukan analisis. Pertama, data dari setiap tahun diolah dengan menggunakan Metode Fast Fourier Transform (FFT) untuk menghasilkan spektrum curah hujan. Kemudian data hasil yang berupa spektrum curah hujan dipergunakan untuk membuat model periodik curah hujan harian. Selisih antara curah hujan yang terukur dengan model periodik curah hujan dipergunakan untuk menghitung model periodik curah hujan. Setelah model periodik dihasilkan, model ini dibandingkan dengan data curah hujan terukur. Koefisien korelasi antara model dan data curah hujan terukur dihitung sebagai ukuran kedekatan antara data dan model curah hujan harian.

\section{Bagan Alir Penelitian}

Untuk menyederhanakan kegiatan penelitian, maka dibuatlah suatu bagan alir penelitian sebagai berikut :

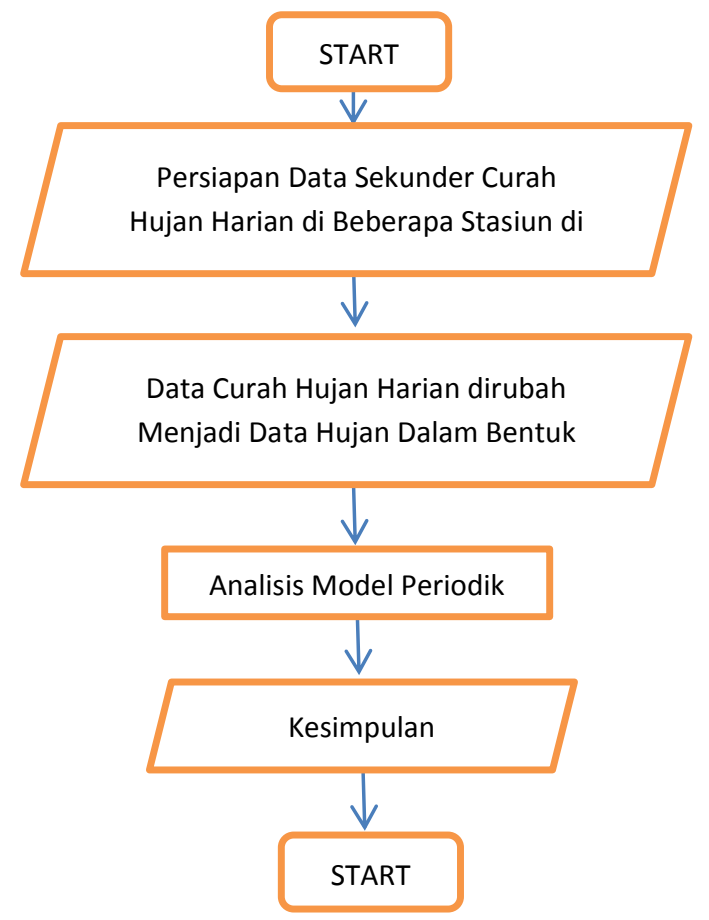

Gambar 1. Diagram Alir Penelitian. 


\section{HASIL DAN PEMBAHASAN}

Pada penelitian ini data curah hujan yang digunakan adalah data stasiun curah hujan di wilayah Way Kandis, yaitu stasiun Way Kandis, stasiun Pahoman, dan stasiun Sumur Batu yang diambil dari Balai Besar Wilayah Sungai MesujiSekampung (BBWSMS). Seluruh lokasi stasiun curah hujan ini langsung berhubungan dengan DAS Mesuji Sekampung dan berada di Wilayah Way Kandis.Dari hasil penelusuran data yang dilakukan, tidak sepenuhnya lengkap. Ada data-data yang hilang atau tidak tercatat oleh petugas pencatat curah hujan BBWSMS.Data yang hilang tersebut berupa data-data curah hujan harian. Untuk datacurah hujan yang tidak lengkap tiap bulannya tentunya tidak dapat dipakai dantidak diikutsertakan dalam mengklasifikasikan data curah hujan tahunan dan dianggap pada tahun itu data curah hujan cacat atau tidak tercatat.

\section{Analisa Data Curah Hujan}

Untuk mengetahui karakteristik komponen periodik dan komponen stokastik curah hujan harian dalam penelitian ini digunakan data curah hujan seri waktu 16 tahun (1997-2013) dari tiga stasiun hujan di Wilayah curah hujan yang digunakan adalah data stasiun curah hujan di wilayah Way Kandis, yaitu stasiun Way Kandis, stasiun Pahoman, dan stasiun Sumur Batu. Dalam pengolahan data curah hujan harian, panjang data curah hujan yang digunakan yaitu 512 hari. Hal ini dimaksudkan bahwa data curah hujan harian dari tahun pertama dan kedua digabungkan, kemudian dari jumlah data yang telah digabungkan tersebut hanya 512 hari yang akan dibaca oleh program $F$ TRANS. Data hujan seri waktu tahun 1997-2013 dari masing-masing stasiun hujan ditunjukkan pada gambar berikut :

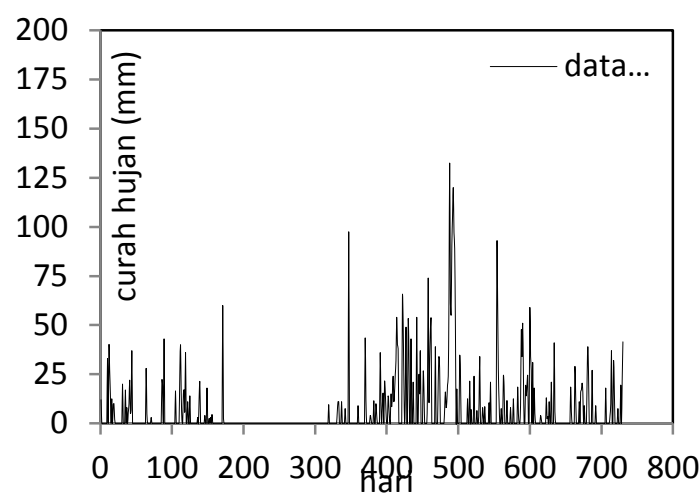

Gambar 2. Curah hujan harian dari stasiun Pahoman.

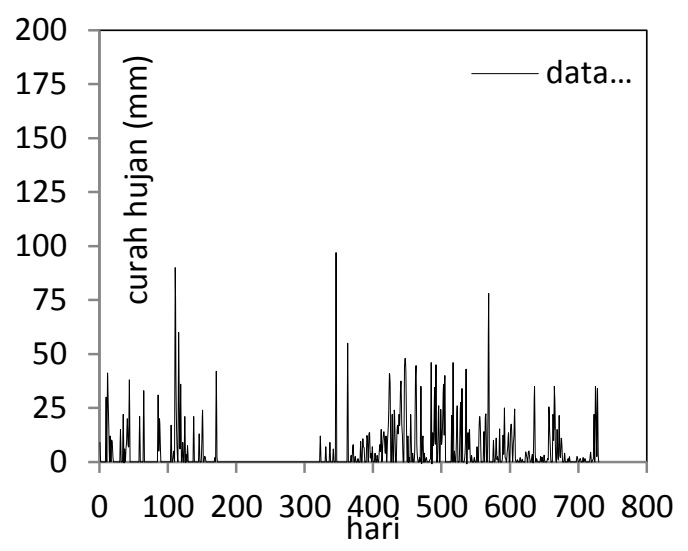

Gambar 3. Curah hujan harian dari stasiun Sumur Batu. 


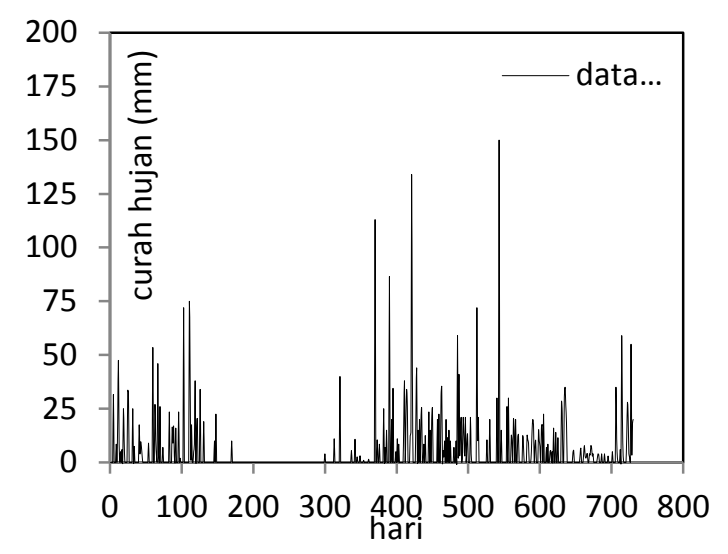

Gambar 4. Curah hujan harian dari stasiun Kandis.

Gambar di atas menunjukkan nilai curah hujan harian dari stasiun curah hujan. Curah hujan yang terjadi pada setiap tahun memiliki jumlah yang tidak seragam. Berdasarkan data yang digunakan dari tahun 1997 sampai dengan tahun 2013, curah hujan maksimum yang terdapat pada stasiun Pahoman yaitu 196,9 mm dan nilai rerata curah hujan maksimumnya sebesar 118,1867 mm. Pada stasiun Sumur Batu nilai curah hujan maksimum sebesar 203 $\mathrm{mm}$ dan nilai rerata curah hujan maksimumnya sebesar 103,7333 mm. Sedangkan pada stasiun Way Kandis nilai curah hujan maksimum sebesar $150 \mathrm{~mm}$ dan nilai rerata curah hujan maksimumnya sebesar $95,5 \mathrm{~mm}$. Dari ketiga stasiun tersebut, curah hujan maksimum terdapat di stasiun Sumur Batu dan nilai rerata curah hujan maksimum yang terjadi nilainya tidak terlalu jauh seperti rerata curah hujan maksimum di stasiun Pahoman dan stasiun Way Kandis yaitu 118,1867 mm dan $95,5 \mathrm{~mm}$.

\section{Spektrum Curah Hujan Harian}

Berdasarkan analisa data curah hujan harian seri waktu yang telah dilakukan sebelumnya, spektrum curah hujan harian seri waktu dihasilkan dengan menggunakan metode FFT (Fast Fourier Transform). Untuk mengetahui spektrum curah hujan harian dipergunakan data curah hujan terukur untuk setiap tahun yaitu dari tahun 1997 sampai dengan 2013 dengan panjang data harian 512 hari. Spektrum data curah hujan harian masing-masing stasiun hujan dipresentasikan pada gambar di bawah ini.

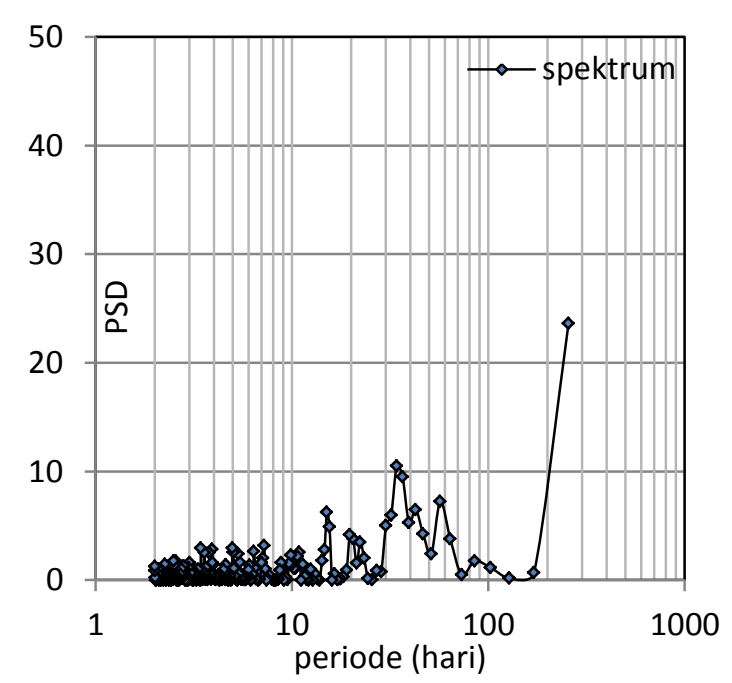

Gambar 5. Spektrum curah hujan (1997) dari stasiun Pahoman 


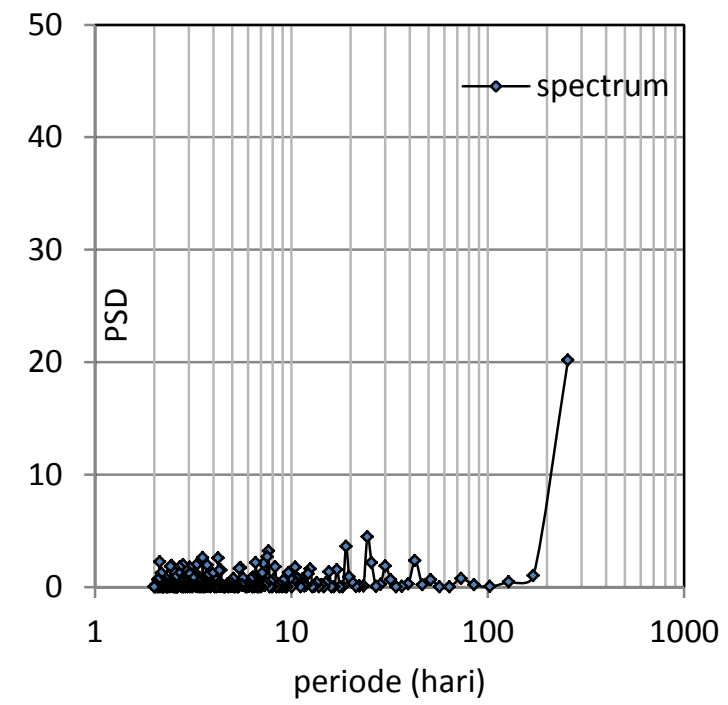

Gambar 6. Spektrum curah hujan (1997) dari stasiun Sumur Batu

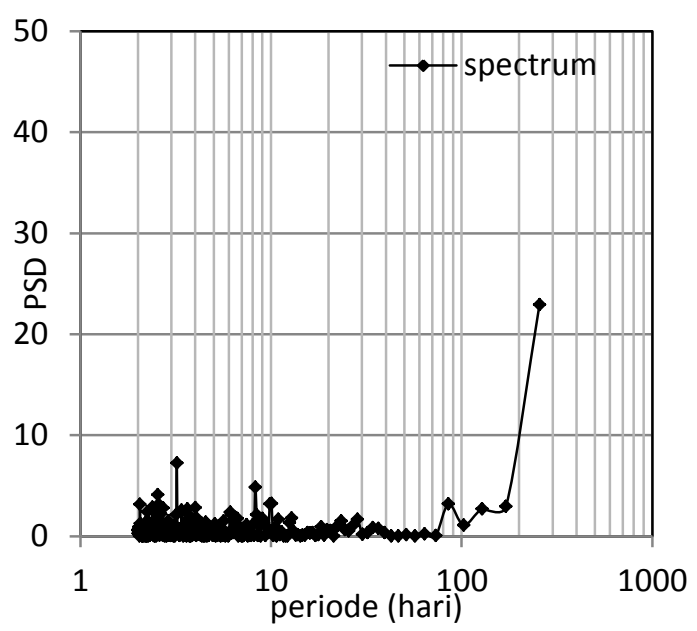

Gambar 7. Spektrum curah hujan (1997) dari stasiun Way Kandis

Dari gambar di atas menunjukkan di stasiun Pahoman telah ditunjukan bahwa besar nilai power spectral density maksimum dari curah hujan harian adalah 23,61 dalam periode 1 tahun atau 365 hari, pada stasiun Sumur Batu besar nilai power spectral density maksimum dari curah hujan harian yang ditunjukkan Gambar 7 adalah 20,1757, dan pada stasiun Way Kandis besar nilai power spectral density maksimumnya adalah 22,9093. Jika dilihat dari nilai power spectral density maksimum yang ada, perbedaan yang terjadi tidak terlalu jauh berbeda dan dapat dilihat juga dari bentuk grafik memiliki pola yang sama. Kondisi ini kemungkinan dipengaruhi faktor-faktor periodik yang mempengaruhi antar stasiunnya. Komponen periodik curah hujan bersifat dominan dari setiap tahunnya ditunjukan oleh nilai periodik maksimum curah hujan yang ada. Spektrum di atas ditunjukan dalam periodik curah hujan dalam fungsi waktu dari periode yang dihasilkan menggunakan metode FFT (Fast Fourier Transform).

\section{Model Periodik Curah Hujan Harian}

Untuk menghitung komponen periodik dari curah hujan harian seri waktu, metode transformasi dapat digunakan untuk menghasilkan dan mendapatkan frekuensi-frekuensi curah hujan periodik. Untuk curah hujan harian selama satu tahun, panjang data 512 hari (data tahun pertama ditambah data tahun berikutnya) dari data curah hujan harian dipergunakan untuk mendapatkan frekuensi-frekuensi curah hujan periodik. Frekuensi yang dihasilkan ditentukan dengan menggunakan sebuah algoritma 
(Cooley dan Tukey, 1965) dimana jumlah data $\mathrm{N}$ dianalisis sebagai pangkat dari 2 , contohnya $\mathrm{N}=2^{\mathrm{k}}$. Dari spektrum curah hujan harian yang telah dihasilkan diperoleh model periodik curah hujan harian sintetik yang ditunjukkan oleh gambar berikut :

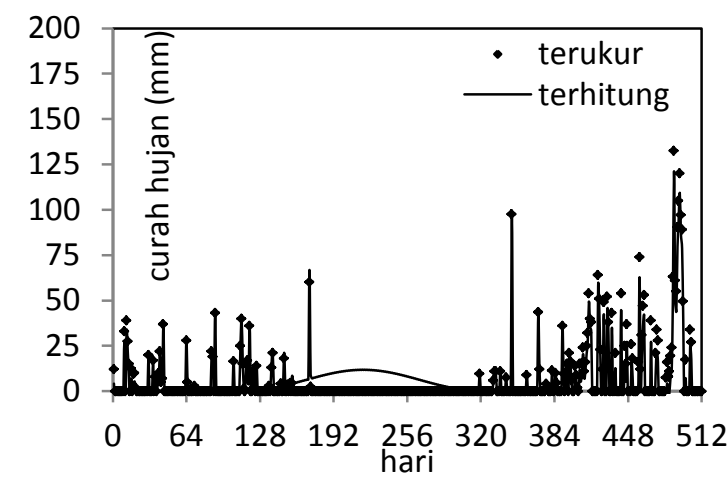

Gambar 8. Model periodik curah hujan harian Pahoman (512) hari

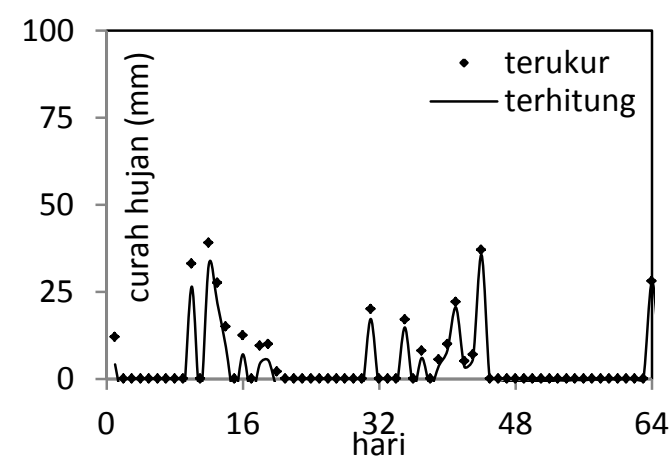

Gambar 9. Model periodik curah hujan harian Pahoman 1997 (64 hari)

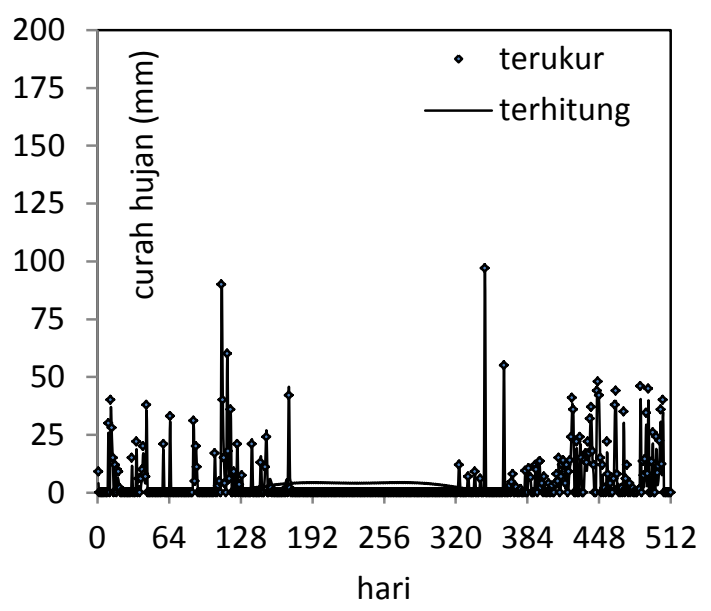

Gambar 10. Model periodik curah hujan harian Sumur Batu 1997 (512 hari)

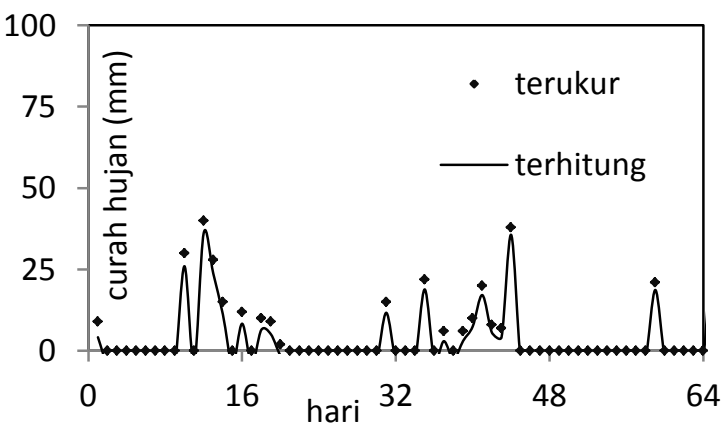

Gambar 11. Model periodik curah hujan harian Pahoman 1997 (64 hari)

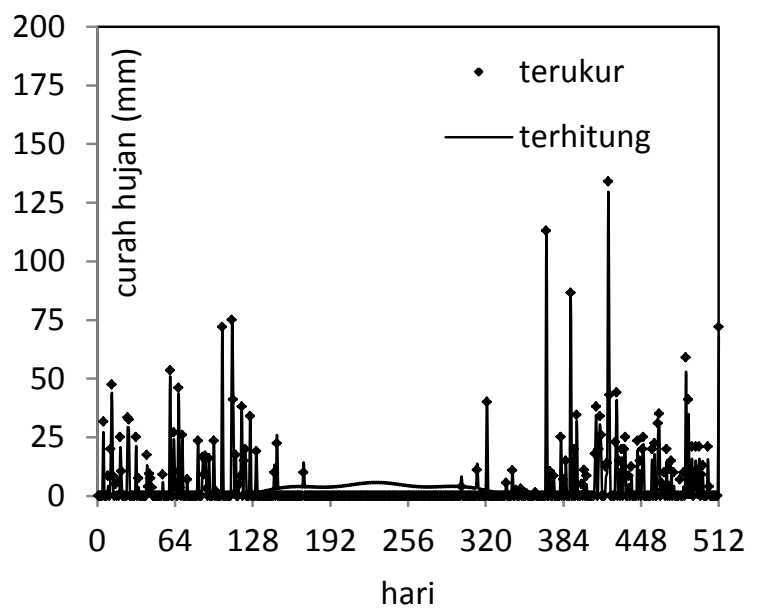

Gambar 12. Model periodik curah hujan harian Way Kandis (512) hari 


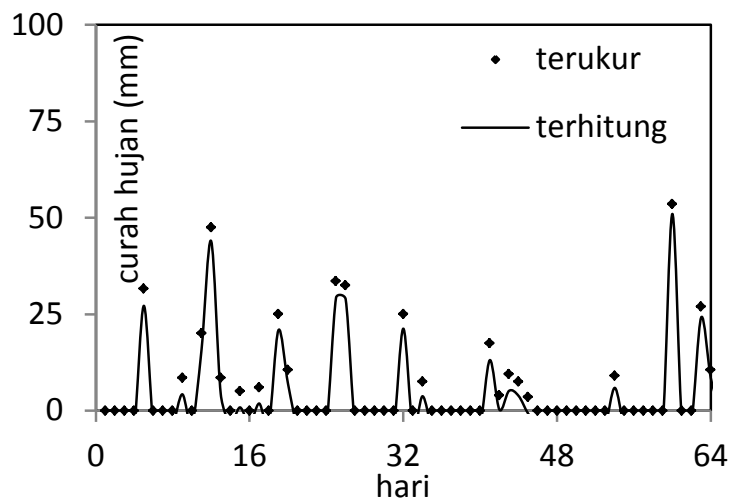

Gambar 13. Model periodik curah hujan harian Way Kandis (64) hari

Pada gambar di atas yang menunjukkan model periodik 512 hari tidak terlihat dengan jelas selisih atau residu antara model periodik dengan data curah hujan terukur, selisih akan terlihat dengan jelas pada gambar yang menunjukkan model periodik 64 hari. Selisih ini merupakan komponen stokastik dari curah hujan, yang dapat membuktikan bahwa komponen periodik mempengaruhi curah hujan yang bersifat tidak menentu.

\section{Koefisien Korelasi}

Selisih antara model periodik dan model stokastik dengan data terukur dapat diketahui koefisien korelasinya. Koefisien korelasi dari penelitian ini dapat dilihat pada gambar berikut ini.

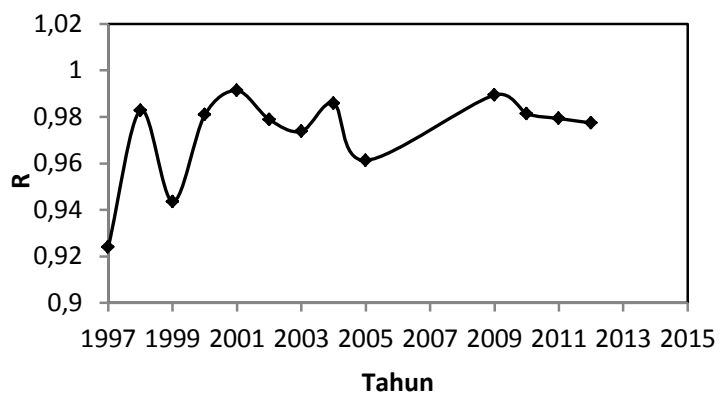

Gambar 14. Koefisien korelasi model periodik stasiun Pahoman

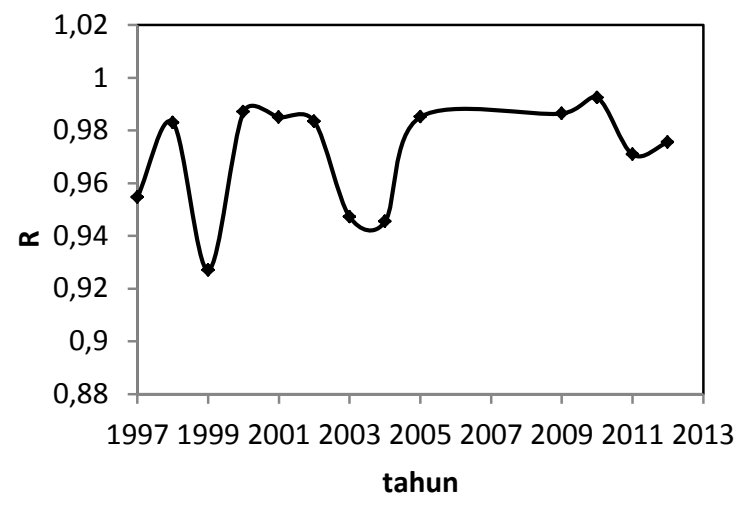

Gambar 15. Koefisien korelasi model periodik stasiun Sumur Batu.

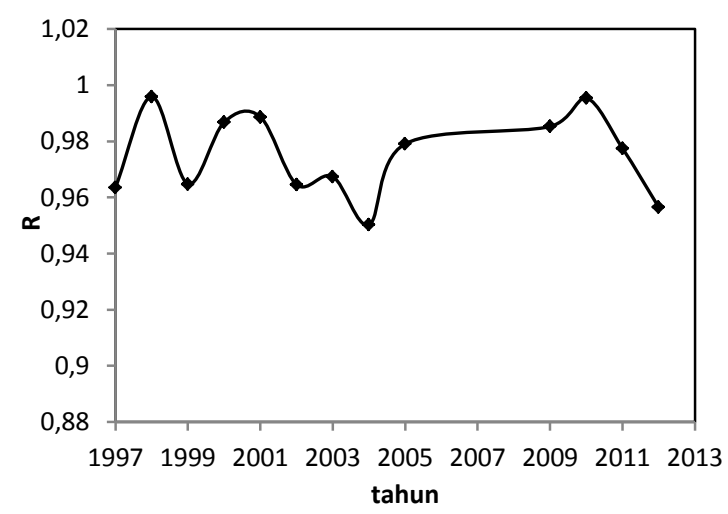

Gambar 16. Koefisien korelasi model periodik stasiun Way Kandis.

Gambar di atas menunjukkan nilai koefisien korelasi model periodik dari ketiga stasiun. Dari pola grafik koefisien korelasi yang terbentuk memiliki hubungan dengan perubahan konsistensi 
data yang ada. Perubahan konsistensi data terjadi di saat pola dari koefisien korelasi tidak mengalami perubahan yang signifikan. Pada Gambar 14, gambar 15, dan gambar 16 menunjukan pada tahun 1997 besar nilai koefisien korelasi ratarata stasiun Pahoman adalah 0,9542, besar nilai koefisien korelasi rata-rata Sumur Batu adalah 0,9113, dan besar nilai koefisien korelasi rata-rata stasiun Way Kandis adalah 0,9256. Jadi nilai rata-rata koefisien dari ketiga stasiun adalah 0,9165. Maka dari nilai koefisien korelasi menunjukkan bahwa nilai yang dihasilkan dari program FFT mendekati data terukur.

\section{KESIMPULAN DAN SARAN}

\section{Kesimpulan}

Berdasarkan uraian dan hasil pembahasan pada penelitian ini dapat disimpulkan bahwa :

1. Dengan menggunakan metode transformasi dapat menghasilkan data curah hujan harian sintetik seri waktu yang hasilnya mendekati data curah hujan terukur.

2. Spektrum curah hujan dari data curah hujan seri waktu digunakan sebagai masukan untuk menghasilkan program periodik stokastik curah hujan buatan untuk mensimulasikan data curah hujan sintetik.
3. Dengan adanya komponen stokastik curah hujan, model curah hujan harian sintetik yang dihasilkan menjadi sangat akurat dengan koefisien korelasi rata-rata model periodik adalah 0,9165,

4. Nilai koefisien korelasi yang dihasilkan hampir mendekati 1, sehingga dapat disimpulkan bahwa metode FFT sangat akurat untuk menghasilkan curah hujan harian sintetik yang signifikan.

\section{Saran}

1. Perlu dikaji dengan menggunakan metode Penggunaan program FFT (Fast Fourier Transform)dan program STOC sangat tergantung pada data curah hujan harian seri waktu. Oleh karena itu data yang digunakan harus memiliki kualitas yang baik.

2. Semakin banyak stasiun curah hujan yang diteliti dalam satu wilayah, maka akan semakin baik karena dapat menghasilkan hujan harian sintetik yang hasilnya sangat signifikan.

\section{DAFTAR PUSTAKA}

Bhakar, S.R., Singh, Raj Vir, Chhajed, Neeraj, and Bansal, Anil Kumar. 2006. "Periodic modeling of monthly rainfall at kota region", ARPN Journal of Engineering and Applied Sciences, vol. 1, no. 3, pp. $36-44$. 
Cooley, James W. Tukey, John W. 1965. An Algorithm for the machine calculation of Complex Fourier Series.Mathematics of Computation. pp. 199-215.

Harto Br, Sri. 1993. Analisis Hidrologi. PT Gramedia Pustaka Utama : Jakarta.

Putra, M. Angga W. 2011. Analisis Periode Dominan Data Curah Hujan Harian di Kota Bandar Lampung. Bandar Lampung : Fakultas Teknik. Universitas Lampung.

Rizalihadi, M. 2002. "The generation of synthetic sequences of monthly rainfall using autoregressive model", Jurnal Teknik Sipil Universitas Syah Kuala, vol. 1, no. 2, pp. 64-68.

Sosrodarsono S., Takeda K. 1985. Hidrologi untuk Pengairan. PT. Pradnya Paramita : Jakarta.

Triatmodjo, Bambang. 2008. Hidrologi Terapan. Beta Offset : Yogyakarta.

Walpole, Ronald E. 1993. Pengantar Statistika edisi ke-3. PT Gramedia Pustaka Utama : Jakarta.

Zakaria, A. 2005a.Aplikasi Program FTRANS. Bandar Lampung: Fakultas Teknik Universitas Lampung.

Zakaria, A. 2005b. Aplikasi Program ANFOR. Bandar Lampung: Fakultas Teknik Universitas Lampung.
Zakaria, A. 2005c .Aplikasi Program Autoreg. Bandar Lampung: Fakultas Teknik Universitas Lampung.

Zakaria, A. 2003.Numerical Modelling of wave Propagation using higher order finite-difference formulas, Thesis (Ph.D.), Curtin University of technology, Perth, W. A., Australia.

Zakaria, A. 2008. The generation of synthetic sequences of monthly cumulative rainfall using FFT and least squares method, Prosiding Seminar Hasil Penelitian \& Pengabdian kepada masyarakat. Vol. 1: 1-15. Bandar Lampung: Universitas Lampung.

Zakaria, Ahmad. 2010. “ A study periodic modeling of daily rainfall at Purajaya region", in Proc. Seminar Nasional Sain \& Teknologi III, 18-19 October 2010, Lampung University, vol. 3, pp. $1-15$.

Zakaria, Ahmad. 2010. “ Studi pemodelan stokastik curah hujan harian dari data curah hujan stasiun Purajaya", in Proc. Seminar Nasional Sain Mipa dan Aplikasinya, 8-9 December 2010, Lampung University, vol. 2, pp. $145-155$. 